\title{
One Nation under God: The Religious Right and the Separation of Church and State in the United States
}

By: Graeme Archibal

Abstract: In the increasingly polarised debate that is American politics, religion and religious belief has garnered a significant amount of attention in recent years, particularly on the right-wing of the political spectrum. Despite the separation of Church and State expressly laid out in the Establishment Clause of the First Amendment to the U.S. Constitution, many Republican politicians and faith-based organisations reject the idea of a secular United States and instead assert the supremacy of Judeo-Christian values in the American political discourse. This paper seeks to examine the activities of right-wing Christian political organisations, who oppose Church/State separation and their connections to U.S. politicians, as well as the deeper causes of the Religious Right's staunch opposition to the Establishment Clause.

\section{Introduction:}

In November 2011, a number of candidates vying for the 2012 Republican presidential nomination attended the "Thanksgiving Family Forum" in Iowa, an event organized by Focus on the Family, the National Organization for Marriage, and the FAMILY Leader, --_ all notable organizations of the Christian right-wing with significant political involvement. ${ }^{-}$Out of the GOP contenders at the time, six attended the forum - only Mitt Romney and Jon Huntsman turned down the invitation. Those in attendance, including Newt Gingrich and Rick Santorum, spoke to the usual positions of the contemporary conservative American, and also seemed to unify around a particular scapegoat for the problems of the United States - secular government and the Supreme Court's steadfast commitment to the separation of church and state. Rick Santorum, formerly the U.S. Senator for Pennsylvania, declared that "we will never have rest because the law does not comport with God's law," specifically referencing abortion, while Newt Gingrich made the following argument to the audience of religious conservatives:

"A country that has been now since 1963 relentlessly in the courts driving God out of public life shouldn't be surprised at all the problems we have. Because we've in fact attempted to create a secular country, which I think is frankly a nightmare". 3

These statements made by the Republican candidates highlight an ideological goal held by many within the American Christian right-wing - to dismantle, or at least to undermine, the longestablished constitutional separation of church and state in the United States, with the intent of bringing about a government that conforms to fundamentalist Christian values.

This paper will argue, and demonstrate, that there is an active campaign by the Christian right-wing to achieve this goal. It will show that well-financed and politically-connected Christian conservative organizations, such as the Family Research Council, Focus on the Family, the Traditional Values Coalition, or the Christian Coalition, deeply oppose the separation of

\footnotetext{
${ }_{1}^{1}$ Benen, Steve. "A Frightening Forum in Iowa." The Washington Monthly. November 20, 2011. Accessed April 1, 2012. http://www.washingtonmonthly.com/political-animal/2011_11/a_frightening_forum_in_iowa033612.php.

2 Jr., Perry Bacon. "GOP Candidates Court Conservative Christians in Iowa." Washington Post. November 21, 2011. Accessed April 1, 2012. http://www.washingtonpost.com/politics/gop-candidates-court-conservative-christians-iniowa/2011/11/19/gIQAbN7VcN_story.html.

${ }^{3}$ Benen, Steve. "Gingrich's Nightmare." The Washington Monthly. November 20, 2011. Accessed April 1, 2012. http://www.washingtonmonthly.com/political-animal/2011_11/gingrichs_nightmare033613.php.
} 
Church and State, and are actively engaged in both political lobbying efforts and judicial challenges with the intent of undermining the law as currently interpreted. It will point to Republican politicians - from the likes of Newt Gingrich, Rick Santorum, and Michele Bachmann, and Members of Congress and congressional candidates - have openly advocated for a dramatically increased presence of religion in public life. ${ }^{4}$ In doing so, these former GOP presidential candidates, among other conservative politicians, aim for a return to the JudeoChristian heritage of the United States - the heritage that they claim the Founding Fathers intended. Most importantly, this paper will reveal the relationships and links between the politicians and these organizations of the religious right, and that those relationships are indicative of a credible threat to the separation of Church and State as it is understood today.

Additionally, this paper will examine the root causes of the religious right's increasingly visible contempt for the secular state. The injection of religion into public life is by no means a new phenomenon - in 1956, the U.S. Congress changed the national motto of the United States from E Pluribus Unum ${ }^{5}$ to the more religiously-toned In God We Trust. ${ }^{6}$ However, the campaign by the Christian right against the separation of Church and State is perhaps stronger than ever, and more politically potent than it has ever been. At the same time, the United States is undergoing significant demographic shifts - including religiosity, which could see Protestant Christianity losing its majority in the U.S. population. Changing demographics are not the only factor to consider; previously fringe ideologies, including Dominion theology and the so-called 'Armageddon factor, ${ }^{7}$ have found growing popularity amongst Christian fundamentalists.

Overall, this paper will show that the Christian right-wing, through its politically-active organizations and those politicians that advocate on its behalf, is actively working to undermine one of the cornerstones of the United States Constitution - the separation of church and state- in order to maintain the historical dominance of Christian theology and its values in the public square.

\section{The Separation of Church and State - Jefferson's Wall and the Culture War}

The first part of the First Amendment of the United States Constitution states that "Congress shall make no law respecting an establishment of religion, or prohibiting the free exercise thereof," 8 enshrining the freedom of religion as an inalienable right of the American people. The First Amendment, through the Establishment Clause, prevents the government of the United States from establishing a state religion, as was the case with European states at the time of the Constitution's writing. Further, the amendment prevents the U.S. government from enacting any legislation that prevents individuals from exercising their religious faith. While the First Amendment is one of the most important entries in the Bill of Rights, it has also been a magnet for controversy. Individuals who believe in secular government see the amendment as establishing a 'separation of church and state', which removes any role or influence of religion in governance and public policy. On the opposing side, there are those who believe that the separation of church and state is unconstitutional and well beyond what the Founding Fathers

\footnotetext{
4 "Made In America." Rick Santorum for President. Accessed April 11, 2012. http://www.ricksantorum.com/madeamerica.

${ }^{5}$ E Pluribus Unum is Latin for "Out of many, one".

${ }^{6}$ U.S. Department of the Treasury. "History of 'In God We Trust"' August 3, 2011. Accessed April 1, 2012. http://www.treasury.gov/about/education/Pages/in-god-we-trust.aspx.

${ }^{7}$ Marci McDonald, The Armageddon Factor: The Rise of Christian Nationalism in Canada (Toronto: Random House Canada, 2010).

${ }^{8}$ U.S. Const. amend. I
} 
intended to limit the role of religion in public life. This has led to the so-called 'culture war' between the secular and sacred in American public life. ${ }^{9}$

Although the phrase 'separation of church and state' does not appear in the First Amendment, or anywhere else in the Constitution, it has generally been accepted as a good descriptor of the current judicial interpretation of the First Amendment. This interpretation is described by Supreme Court Justice Hugo Black, speaking for the majority in the 1947 case Everson v. Board of Education, who stated that "the First Amendment has erected a wall between church and state. That wall must be high and impregnable. We could not approve of the slightest breach." ${ }^{, 0}$ This judicial interpretation finds its grounding in U.S. history. Thomas Jefferson first coined the phrase a 'wall of separation' in his 1802 letter to the Danbury Baptist Association, ${ }^{11}$ which had requested his assistance as a religious minority in the state of Connecticut. ${ }^{12}$ Additionally, during Jefferson's presidency, he refused to acknowledge days of prayer or fasting, believing that the federal government had no business even "indirectly... recommend[ing]" ${ }^{" 13}$ certain religious practices. James Madison, who initially wrote the First Amendment, opposed proposals that would have allowed for state funding for religious education. ${ }^{14}$ Furthermore, in 1797 President John Adams signed the Treaty of Tripoli, which expressly declared that "the Government of the United States is not, in any sense, founded on the Christian religion." 15 The judicial branch of the United States has largely upheld this interpretation of the separation of church and state. From the landmark Supreme Court case Engel v. Vitale in 1962 which ended school-sponsored prayer ${ }^{16}$ to the more recent district court case Kitzmiller v. Dover Area School District in 2004 which determined the teaching of intelligent design to be in violation of the separation. From the perspective of the courts, the separation of Church and State is seemingly absolute.

However, the Christian right-wing remains in vigorous opposition to the rulings of the judicial system. David Kupelian, best known for his work with WorldNetDaily.com, a deeply conservative news website, describes Church-State separation as a 'myth' and 'the big lie' in his book The Marketing of Evil. ${ }^{17}$ Kupelian and others assert that the touted separation is the result

\footnotetext{
${ }^{9}$ Hunter, James D. "The Culture War and the Sacred/Secular Divide: The Problem of Pluralism and Weak Hegemony." Social Research 76, no. 4, 1307-322. Accessed February 13, 2012. Political Science Complete, EBSCOhost.

${ }^{10}$ David Kupelian, The Marketing of Evil: How Radicals, Elitists, and Pseudo-experts Sell Us Corruption Disguised as Freedom (Nashville, TN: WND Books, 2005), pg. 47

${ }^{11}$ Dawson, Joesph M. "The Meaning of the Separation of Church and State in the First Amendment." Journal of Church and State 50, no. 4 (2008) Pg. 680

12 "Jefferson's Wall of Separation Letter." Thomas Jefferson to Danbury Baptist Association. January 1, 1802. Accessed April 1, 2012. http://www.usconstitution.net/jeffwall.html.

${ }^{13}$ Morone, James A. "Jefferson's Rickety Wall: Sacred and Secular in American Politics." Social Research 76, no. 4, 1199-226. Accessed April 11, 2012. Wilson OmniFile Full Text Select Edition. Pg. 1199

${ }^{14}$ J. Brent Walker, "The Meaning of Separation of Church and State in the First Amendment," Journal of Church \& State 50, no. 4 (2008): 693, accessed April 11, 2012, MasterFILE Premier.

${ }^{15}$ Garrett Epps, "Constitutional Myth \#4: The Constitution Doesn't Separate Church and State," The Atlantic, June 15, 2011, accessed April 1, 2012, http://www.theatlantic.com/national/archive/2011/06/constitutional-myth-4-theconstitution-doesnt-separate-church-and-state/240481/.

${ }^{16}$ The Pew Forum on Religion \& Public Life. Religion in the Public Schools. 2007. Pg. 3

${ }^{17}$ David Kupelian, The Marketing of Evil: How Radicals, Elitists, and Pseudo-experts Sell Us Corruption Disguised as Freedom (Nashville, TN: WND Books, 2005), Pg. 39
} 
of an activist court system ${ }^{18}$ that wishes to "[transform] America into a de facto atheistic, secular state" ${ }^{\prime 19}$ by removing God from the public square. For Kupelian and those who agree with him, the interpretation of the Establishment Clause by the Supreme Court is a gross violation of what the Founding Fathers intended - a country based on Judeo-Christian values. Kupelian declares that, at the time of the country's foundation, "Christianity permeated America from top to bottom," Christian nation. As such, any attempt by the courts to limit Christianity - from ending school prayer to removing a Ten Commandments statue from the Alabama Supreme Court building - is a desecration of what the United States is 'supposed' to be.

The arguments made by the Christian right against the separation of Church and State have not gone unchallenged. Joseph Dawson, the former executive director of the Baptist Joint Committee on Public Affairs, has argued that by following the 'Christian nation' thesis, or by demonstrating a preference for one religion over another, religious freedom may be threatened ${ }^{21}$. Dawson argues that the attacks upon the wall of separation by the Christian right are not motivated by a desire to realize the intended meaning of the Founding Fathers, but to garner special favours and preferential treatment from the government. ${ }^{22}$ For Dawson, if those who seek such gains are successful in subverting the historical interpretation of the Constitution for one of their own, it would be "the death knell of religious liberty in the United States." 23

The clash between these two deeply opposing viewpoints - the secular versus the sacred | - has manifested itself into a 'culture war'. It has pervaded almost every sector of public policy, from education to individual rights. In Texas, the State Board of Education, responsible for determining the curriculum and textbook contents, has become dominated by Christian conservatives who have altered American history to fit their worldview, arguing that the changes were needed to account for the "extreme left views that liberals had introduced in earlier times." 24 Organizations such as OneMillionMoms have led public campaigns to censor any media that does not conform to strict Christian conservative standards. ${ }^{25}$ Christians across the United States have vigorously campaigned against same-sex marriage, citing their religious values as justification. The issue of prayer in schools remains as prevalent as ever, despite the Supreme Court's 1947 ruling, and sees new legal challenges a few times every year. The culture war over the place of religion in public life remains as intense as ever - and there are powerful organizations and politicians that have sided firmly with the cause of the Christian right. With the religious liberty of the United States at stake, as Joseph Dawson asserts, this battle is perhaps more important than ever.

\footnotetext{
18 An activist court system refers to the belief that the judicial branch uses its power to create, rather than interpret law.

19 Ibid. Pg. 40

${ }^{20}$ David Kupelian, The Marketing of Evil: How Radicals, Elitists, and Pseudo-experts Sell Us Corruption Disguised as Freedom (Nashville, TN: WND Books, 2005), Pg. 41

${ }^{21}$ J. Brent Walker, "The Meaning of Separation of Church and State in the First Amendment," Journal of Church \& State 50, no. 4 (2008): 694, accessed April 11, 2012, MasterFILE Premier.

${ }^{22}$ Joesph M. Dawson, "The Meaning of the Separation of Church and State in the First Amendment," Journal of Church and State 50, no. 4 (2008): 680.

${ }^{23}$ Ibid.

${ }^{24}$ R. V. Pierard and C. McDaniel, "Reappropriating History for God and Country," Journal of Church and State 52 , no. 2 (2010): 195, doi:10.1093/jcs/csq080.

25 "One Million Moms.com - Other Active Issues," One Million Moms.com, accessed April 11, 2012, http:/www.valueis.com/visit/onemillionmoms.com/activism.
} 


\section{Christian Political Advocacy Organizations:}

A significant political advantage of the Christian right-wing is its strong organization. Christian groups are highly coordinated and well-financed, and are as such, are able to exert pressure on both politicians sympathetic to their cause and on the so-called 'values voter' - the traditional, usually evangelical Christian American citizen. ${ }^{26}$ Among the largest and most active Christian organizations are the Family Research Council, the Traditional Values Coalition, the Christian Coalition, and Focus on the Family. Each maintaining a decidedly political agenda, and engage in many initiatives to advance the Christian conservative cause - including a strong opposition to the separation of church and state. From public relations campaigns to political endorsements and donations, these organizations aggressively assert the dominance of fundamentalist Christian theology in the public square, with the intention of undermining the secular society that the First Amendment has created.

The Family Research Council (FRC) is a public policy think-tank in Washington, D.C. that advocates for "family in our nation's halls of power.",27 Established in 1983 by James Dobson, a prominent evangelical leader, the Family Research Council has worked to "advance faith, family, and freedom in public policy and public opinion,"28 through "policy research, public education on Capitol Hill and the media, and grassroots mobilization." 29 According to the website, the organization follows a number of social issues dear to the hearts of Christian conservatives - marriage, sexuality, bioethics, media content, and religious liberty. However, as opposed to the understanding of religious liberty by the likes of the Supreme Court of the United States or Joseph Dawson, the FRC strictly adheres to an interpretation much like Kupelian. According to the FRC, religious liberty in the United States must respect the "Judeo-Christian worldview [that has] provided a sound basis for the flourishing of our national culture and our political system,"30 which immediately hints at a belief in religion's inherent role in government. The FRC goes further, stating that they "deny that minority religions are entitled to greater protection than members of the country's majority Christian faith," ${ }^{31}$ highlighting the organization's interest in preferential treatment of Christianity by the courts and government of the United States - an idea which is deeply contradictory to the idea of religious freedom to those that follow the historical and judicial interpretation of the First Amendment.

The Family Research Council openly rejects the Supreme Court's 1947 ruling on the meaning of the Establishment Clause of the First Amendment, declaring that "[the Founders] did not intend a "wall of separation" between all expressions of faith in God and all aspects of public life." 32 The FRC goes beyond the 'wall of separation' and openly advocates for "public officials [to] proclaim their faith in public settings and to bring their religiously-informed moral values to bear in election campaigns and public policy decisions" $" 33$. From these statements, it is clear that the FRC is fundamentally against the separation of Church and State, as well as a demonstrated belief that Christian values should be a source of guidance in public policy decisions.

\footnotetext{
26 "Glossary of Religious and Spiritual Terms," ReligiousTolerance.org, October 15, 2008, accessed April 11, 2012, http://www.religioustolerance.org/gl_v.htm.

27 "About FRC," Family Research Council, accessed April 1, 2012, http://www.frc.org/about-frc.

${ }^{28}$ Ibid.

${ }^{29}$ Ibid.

${ }^{30}$ Family Research Council, "Religion and Culture," , accessed April 1, 2012, http://www.frc.org/religion-culture.

${ }^{31}$ Ibid.

${ }^{32}$ Ibid.

${ }^{33}$ Ibid.
} 
There are many Christian conservative organizations that adhere to a similar ideology regarding Church/State separation as the Family Research Council. Unlike some other, less active organizations, however, the FRC does not limit itself to listing policy positions on its website. One of the defining features of the FRC is its dedication to political advocacy, in terms of both lobbying members of Congress and election financing. This is done primarily through the Family Research Council's legislative action arm - FRC Action. FRC Action is described as a "non-profit education and lobbying organization...dedicated to preserving and advancing the interests of family, faith, and freedom in the political arena," 34 which it claims to have done through video campaigns, advertising, and by providing educational material on traditional American values to political parties. FRC Action's website lists seven key policy areas that they specifically focus their advocacy on. These policy areas are the usual suspects in terms of social conservatism - a dedication to the pro-life cause and traditional marriage, an aggressive foreign policy, and neoliberal tax policies. Not surprisingly, the separation of Church and State is also a major component of FRC Action's platform, making up three points out of the seven listed. FRC Action seeks "[to restore the] the constitutional balance in relations between church and state," "judicial restraint and respect for the original intent of the framers of the Constitution", and "renewal of ethical monotheism and traditional Judeo-Christian standards...to which the founding fathers appealed in the Declaration of Independence"35. As previously shown, U.S. history shows that the Supreme Court's rulings are reflective of the intentions of the Founders, thus FRC Action's position is in fact advocating for a changed definition of church/state separation - one that gives preference to Christianity over other faiths.

The Family Research Council and FRC Action back their words with action that takes the form of lobbying, candidate financing and endorsements, as well as advertising campaigns. According to the Center for Responsive Politics, an organization which maintains a detailed database on the activities of lobbying firms and political action committees, the Family Research Council has lobbied for a wide variety of bills that address social conservative causes - largely focused on abortion, same-sex marriage and stem cell research ${ }^{36}$. Bills that affect the separation of church and state are less common in the U.S. Congress, but on the occasions that such bills do appear, the FRC is usually listed as a lobbyist. One such bill is the U.S. Senate bill S.520, The Constitution Restoration Act of 2005, which was introduced by Senator Richard Shelby of Alabama $^{37}$. The summary of the bill is as follows:

Amends the Federal judicial code to prohibit the U.S. Supreme Court and the Federal district courts from exercising jurisdiction over any matter in which relief is sought against an entity of Federal, State, or local government or an officer or agent of such government concerning that entity's, officer's, or

\footnotetext{
34 "About," FRC Action, accessed April 1, 2012, http://www.frcaction.org/about-us.

35 Ibid.

36 “Lobbying - Family Research Council", accessed December 2, 2012, http://www.opensecrets.org/lobby/clientbills.php?id=D000025756\&year=2012

37 Senate, Bill Summary \& Status, 109th Cong., S. S.520, accessed April 2, 2012, http://thomas.loc.gov/cgibin/bdquery/z?d109:SN00520.
} 
agent's acknowledgment of God as the sovereign source of law, liberty, or government. $^{38}$

To summarize, the bill aims to prevent the U.S. judicial system, all the way to the Supreme Court, from ruling on cases involving the role of God in government. Although the bill died in committee, the Family Research Council did lobby on the bill's behalf. ${ }^{39}$ The House of Representatives' bill - the also long-dead H.R. 1070 - was introduced by Rep. Robert Aderholt, and had fifty co-sponsors. ${ }^{40}$ Among these co-sponsors were Rep. Steve King, Rep. Marilyn Musgrave, and Rep. Mike Pence, ${ }^{41}$ each of whom has received financial contributions from the Family Research Council in subsequent election cycles. Rep. King received $\$ 5,000$ from the FRC in both the 2010 and 2012 election cycles, Rep. Musgrave received \$2,000 in 2008, and Rep. Pence received $\$ 500$ and $\$ 1,000$ in 2008 and 2010 respectively $^{42}$. Although these donations may not seem very large or significant, it is worth noting that for Rep. King in the 2012 election cycle and for Rep. Pence in the 2010 election cycle. ${ }^{43}$ the FRC is among each member's top 20 contributors. These figures indicate that those members of Congress who vote against the separation of church and state can and do receive donations from the Family Research Council for their support.

Representatives King, Musgrave, and Pence are members of the Republican Party, as are all recipients of FRC donations. In the 2010 election cycle, the FRC engaged in the following activites: donated over $\$ 84,000$ directly to Republican candidates, ${ }^{44}$ spent over $\$ 88,000$ promoting Republican candidates, and $\$ 176,000$ targeting Democrats. ${ }^{45}$ The 2008 election cycle tells a similar story, with over $\$ 150,000$ spent directly targeting then-candidate Barack Obama and over \$73,000 for Republican candidates. Not surprisingly, the FRC's donations and expenditures have been directed to the most conservative of Republicans, particularly those who have expressed decidedly anti-secular views. These donations have included $\$ 12,435$ in 2008 in favour of Michele Bachmann, ${ }^{46}$ one of the leading figures of the social conservative movement and a former candidate for the 2012 GOP Presidential nomination. In 2010, Bachmann also received a $\$ 3,000$ donation from the FRC for her Congressional re-election campaign. Christine O'Donnell, who mounted an unsuccessful bid for the Delaware U.S. Senate seat in the same year and shared similar views on the separation of Church and State, received a donation of $\$ 4,000 .{ }^{47}$

\footnotetext{
${ }^{38}$ Ibid.

${ }^{39}$ Center for Responsive Politics, "Lobbying Spending Database S.520, 2010 | OpenSecrets," OpenSecrets.org, accessed April 2, 2012, http://www.opensecrets.org/lobby/billsum.php?id=77065.

${ }^{40}$ House, Bill Summary \& Status - Co-Sponsors, 109th Cong., H. H.R. 1070, accessed April 2, 2012, http://thomas.loc.gov/cgi-bin/bdquery/z?d109:HR01070:@@@.

41 Ibid.

${ }^{42}$ Center for Responsive Politics, "Contributions to Federal Candidates," OpenSecrets.org: Money in Politics, accessed April 2, 2012, http://www.opensecrets.org/pacs/pacgot.php?cycle=2012.

${ }^{43}$ Center for Responsive Politics, "Top 20 Contributors," OpenSecrets.org, accessed April 2, 2012, http://www.opensecrets.org/politicians/contrib.php?cycle=2012.

${ }^{44}$ Center for Responsive Politics, "Family Research Council Summary," OpenSecrets.org: Money in Politics, accessed April 2, 2012, http://www.opensecrets.org/pacs/lookup2.php?strID=C00452383.

${ }^{45}$ Center for Responsive Politics, "Family Research Council Independent Expenditures," OpenSecrets.org: Money in Politics, accessed April 2, 2012, http://www.opensecrets.org/pacs/indexpend.php?cmte=C00452383.

46 Ibid.

${ }^{47}$ Center for Responsive Politics, "Contributions to Federal Candidates," OpenSecrets.org: Money in Politics.
} 
FRC Action is not limited to donations and campaigns on behalf of certain candidates. FRC Action also openly endorses large slates of Congressional candidates in each election cycle, with the hope of bringing substantive change to the state and federal legislatures of the nation to advance their political agenda, as is the case with most political advocacy organizations. While the endorsements of some organizations may not have much impact, it does appear that FRC Action's endorsed candidates are winning - and slowly but surely contributing to a shift in the legislative landscape in favour of the Christian right. In the 2010 midterm elections, FRC Action endorsed 183 candidates for Congress, of which 157 won - an 86 per cent success rate. ${ }^{48}$ While these victories are not exclusively due to the endorsement of the FRC, it still indicates that there are a large number of congressional members that are sympathetic to the positions of the $\mathrm{FRC}-$ including issues of church/state separation.

The Family Research Council has consistently been the Christian right's largest political advocate in Washington, D.C. since 2010, spending \$110,000 in that year and \$107,000 in 2011 on lobbying efforts. ${ }^{49}$ However, it is not alone - the Traditional Values Coalition and the Christian Coalition are two Christian conservative organizations that remain particularly prominent in the affairs of Capitol Hill. The Traditional Values Coalition claims to be among "the leading [voices] in the halls of Congress for the Bible-based traditional values that created and preserved our nation," "with explicit support for "championing Judeo-Christian values in the public square." ${ }^{, 51}$ The Traditional Values Coalition (TVC) spent \$101,200 on lobbying in both 2010 and 2011, and \$325,900 in 2008, ${ }^{52}$ and lobbied with the FRC on the previously explained Constitution Restoration Act of 2005. In electoral politics, the TVC has been significantly less active in recent years; however, it has previously donated to the individuals including Marilyn Musgrave and Senators Robert Burr and Wayne Allard ${ }_{2}^{53}$ who did sponsor the House and Senate versions of the Constitution Restoration Act respectively. The Christian Coalition, the brainchild of evangelist media mogul Pat Robertson, has declined significantly in its influence within the Republican Party and the Christian right, but none-the-less remains worthy of a mention. Since 1998, the Christian Coalition has spent over $\$ 17$ million on lobbying efforts, however by 2010 this number fell to a mere $\$ 50,000$, and as of 2011 the Christian Coalition has not reported any lobbying expenses. ${ }_{-}^{54}$

Another prominent Christian organization is Focus on the Family. Focus on the Family is not a policy or lobbying client like the Family Research Council, but a global Christian ministry with the belief - among others - that "Christians have a responsibility to promote truth and social policy." 55 In line with this belief, Focus on the Family has expressed serious concern about the

\footnotetext{
${ }^{48}$ FRC Action, "Election Recap: The Return on Your Investment," news release, FRC Action.org.

${ }^{49}$ Center for Responsive Politics, "Republican/Conservative: Lobbying, 2011," OpenSecrets.org, accessed April 3, 2012, http://www.opensecrets.org/industries/lobbying.php?ind=Q01++.

Traditional Values Coalition, "About," About - Traditional Values Coalition, accessed April 4, 2012 , http://www.traditionalvalues.org/content/about.

51 Ibid.

${ }^{52}$ Center for Responsive Politics, "Republican/Conservative: Lobbying, 2011." OpenSecrets.org.

${ }^{53}$ Center for Responsive Politics, "Traditional Values Coalition Independent Expenditures," OpenSecrets.org, accessed April 4, 2012, http://www.opensecrets.org/pacs/indexpend.php?cmte=C00278283.

${ }^{54}$ Center for Responsive Politics, "Christian Coalition," OpenSecrets.org, accessed April 10, 2012, http://www.opensecrets.org/lobby/clientsum.php?id=D000048653.

55 "About Us - Focus on the Family," Focus on the Family, accessed April 10, 2012, http://www.focusonthefamily.com/about_us.aspx.
} 
separation of Church and State - going as far as creating an entire section dedicated to the issue on their website. ${ }^{56}$ Focus on the Family, like much of the Christian right, argues for the 'Christian nation' thesis that history has repeatedly shown to be false - stating that the judicial decisions that took the Bible and prayer out of public schools "clearly negate the Founding Fathers' presupposition of America's Christian identity" "57. As such, Focus on the Family advocates for judicial reform, ${ }^{58}$ placing the blame for the "misapplication" of the Establishment Clause squarely on the Supreme Court of the United States. ${ }^{59}$

Like the Family Research Council, Focus on the Family maintains a political advocacy affiliate, CitizenLink. ${ }_{-}^{60}$ In the 2010 midterm elections, CitizenLink spent over $\$ 550,000$ on behalf of Republican candidates, ${ }^{61}$ however the main initiative of CitizenLink and Focus on the Family is public policy awareness. While most of the organization's campaigns surround hot social issues like abortion or same-sex marriage, the overarching goal of CitizenLink and Focus on the Family is to gather public support for U.S. policies to be guided by Judeo-Christian values, which in itself violates the spirit of the separation of Church and State and secular governance. According to CitizenLink’s 2010 Annual Report, the organization spent over \$4.7 million on these public policy awareness campaigns, ${ }^{62}$

\section{The Politicians}

While organizations like Focus on the Family, the Family Research Council, or the Traditional Values Coalition strongly push the Christian right's political agenda in Washington, those politicians that are sympathetic and receptive to their arguments (and donations) cannot be ignored. In the race for the 2012 GOP Presidential nomination, the anti-secular views of rightwing Republicans, like Newt Gingrich, Rick Santorum or Michele Bachmann, have become quite visible. Current and former Members of Congress, such as Steve King and Marilyn Musgrave, have well-established records of standing against the separation of church and state. The list is by no means exhaustive, however, it does not mean that the U.S. government is controlled by anti-secular Christian conservatives. These individuals, however, represent that the Christian right does have at least some support amongst the lawmakers of the United States.

Although Newt Gingrich - former Speaker of the House of Representatives and champion of the so-called Republican Revolution of 1994 - lost the 2012 GOP nomination race by a significant margin, his views on church/state separation are worth noting, as they indicate a desire by the Christian right to gain control of the executive branch. As the quote that opened this paper revealed, Newt Gingrich is no fan of the separation of church and state - he has stated that

\footnotetext{
56 "The Separation of Church and State," Focus on the Family, accessed December 2, 2012, http://www.focusonthefamily.com/socialissues/social-issues/separation-of-church-and-state.aspx

${ }^{57}$ Focus on the Family, "The Separation of Church and State," Social Issues, 2008, accessed April 10, 2012, http://www.focusonthefamily.com/socialissues/social-issues/separation-of-church-and-state.aspx.

58 Ibid.

${ }^{59}$ Ibid.

60 "About Us | CitizenLink," CitizenLink.com, accessed April 10, 2012, http://www.citizenlink.com/about-us/.

${ }^{61}$ Center for Responsive Politics, "CitizenLink Outside Spending," OpenSecrets.org, accessed April 10, 2012 , http://www.opensecrets.org/outsidespending/detail.php?cmte=CitizenLink.

${ }^{62}$ CitizenLink, 2011 Annual Report, report, September 2011, http://www.citizenlink.com/uploads/2010/07/FY2011FOTF295213_7_2011AnnualReport_CitizenLink_INTERACTIVE1.pdf.
} 
"to be American is to be aware that our power comes from a Creator," 63 has introduced a Constitutional Amendment for school prayer, ${ }^{64}$ and openly supports the Christian nation thesis, advocating to "restore America to her Judeo-Christian heritage." ${ }^{65}$ Gingrich's position on Church/State separation is not limited to rhetoric - as part of his policy platform in the 2012 race, he promised a 'day one' executive order to establish a 'Presidential Commission on Religious Freedom', to "document threats or impediments to religious freedom in the United States"66. The proposal makes clear that the Commission is needed in response to "anti-religious misconceptions of the First Amendment which are then reinforced by judges determined to impose their own views on other citizens" ". As such, the Commission would "investigate the interpretation of the courts throughout the U.S. of the First Amendment's protection of religious freedom",68, and to investigate the "the status of religious freedom and freedom of conscience in schools from primary to university level",69. These actions, in rejecting the established interpretation of the Establishment and Free Exercise Clauses of the First Amendment indicate the intention of a Gingrich presidency to - with the support of Christian conservatives undermine the separation of Church and State as it exists in the United States. While Gingrich did not clinch the nomination, promises such as this commission show that the challenge to church/state separation remains as strong as ever.

Like Gingrich, former Pennsylvania Senator Rick Santorum is no longer a contender in the 2012 Republican primaries. However, his positions on church/state separation are also worthy of mention and further show the active political campaign against secularism. Santorum's campaign was described as "possibly the most religiously-based presidential campaign...perhaps in American history" "70, a statement which is reflective of many of Santorum's comments on the campaign trail. Santorum claimed that he did not believe that "the separation of Church and State [was] absolute", ", and that a past speech by President John F. Kennedy reaffirming the strength of that separation made him "almost [throw] up",72. Santorum further declared that he believed that "the idea that the church can have no influence or no involvement in the operation of the state is absolutely antithetical to the objectives and vision of our country" ${ }^{, 73}$. Notably, Santorum

\footnotetext{
${ }^{63}$ Sarah Posner, "Gingrich's Anti-Secularism Greatest Hits | Religion Dispatches," ReligionDispatches, November 29, 2011, accessed April 10, 2012, http://www.religiondispatches.org/dispatches/sarahposner/5445/gingrich\%E2\%80\%99s_antisecularism_greatest_hits.

${ }^{64}$ Sarah Posner, "Gingrich's Anti-Secularism Greatest Hits | Religion Dispatches," ReligionDispatches, November 29, 2011.

${ }^{65}$ Ibid.

${ }^{66}$ Newt 2012, "Presidential Commission on Religious Freedom," Presidential Commission on Religious Freedom, December 19, 2011, accessed April 10, 2012, http://www.scribd.com/doc/76090650/Presidential-Commission-onReligious-Freedom.

${ }^{67}$ Ibid.

${ }^{68}$ Ibid.

${ }^{69}$ Ibid.

${ }^{70}$ Susan Brooks Thistlethwaite, "Was Santorum Running for Theologian-in-chief?," Washington Post, April 10, 2012, accessed April 11, 2012, http://www.washingtonpost.com/blogs/guest-voices/post/was-santorum-running-fortheologian-in-chief/2012/04/10/gIQARZYp8S_blog.html.

${ }^{71}$ Alana Horowitz, "Santorum: Separation Of Church And State 'Makes Me Want To Throw Up'" The Huffington Post, February 26, 2012, accessed April 11, 2012, http://www.huffingtonpost.com/2012/02/26/santorum-churchand-state_n_1302246.html.

${ }^{72}$ Ibid.

${ }^{73}$ Ibid.
} 
also garnered much of his support from the Christian right, claiming $32.9 \%$ of evangelical voters in the primary race ${ }^{74}$, more than the other Republican candidates. Additionally, Santorum seemed to be the favourite candidate of organizations like FRC Action, which expressed disappointment at the suspension of his campaign in the April of 2012. ${ }^{75}$

The Christian right's campaign against the separation of Church and State is not limited to presidential candidates, as seen in the actions of members of Congress such as current Representatives (and former 2012 GOP Presidential candidate) Michele Bachmann of Minnesota or Steve King of Iowa, and former Representative Marilyn Musgrave of Colorado. In 2006, Bachmann - leader of the Tea Party Caucus in the House of Representatives - claimed that public schools "are teaching children that there is separation of church and state, and I am here to tell you that is a myth" "76 a claim she repeated during a GOP debate in September 2011, ironically citing Jefferson's letter to the Danbury Baptists ${ }^{77}$. Rep. Steve King was not only a cosponsor of the Constitution Restoration Act, but also was the sole 'no' vote in a 2009 resolution recognizing slave labour's contribution to the Capitol Building. In regards to his vote, Rep. King declared that "the architect of the Capitol and liberal activists opposed every reference to America's Christian heritage", , and that the resolution was "just the latest example of a several year effort by liberals in Congress to scrub references to America's Christian heritage from our nation's Capitol [Building]"79. He further stated that "[the] Judeo-Christian heritage is an essential foundation stone of our great nation" ${ }^{~}$, highlighting his adherence to the Christian nation thesis, and deep opposition to the separation of church and state. Marilyn Musgrave, who was voted out of office in the 2008 election, was given a 0 per cent score by Americans United for the Separation and Church and State ${ }^{81}$, and co-sponsored a House resolution to recognize the importance of Christianity worldwide, which "[acknowledged] the role played by Christians and Christianity in the founding of the U.S... and rejected bigotry and persecution directed towards Christians, both in the U.S. and worldwide" ${ }^{\prime 82}$. While these are just a few examples of Congressional representatives with strong stances against the separation of Church and State, it is worth noting that Bachmann, King, and Musgrave all received campaign contributions from the Family Research Council as previously mentioned.

\section{Answering the Why - Christian Dominion and Demographics}

\footnotetext{
${ }^{74}$ David Gibson, "Evangelicals Voting in Record Numbers in GOP Primaries," Washington Post, March 16, 2012, accessed April 11, 2012, http://www.washingtonpost.com/national/on-faith/evangelicals-voting-in-record-numbersin-gop-primaries/2012/03/16/gIQAlsi5GS_story.html.

${ }^{75}$ FRC Action, "Santorum's Bid Ends - Values Campaign Continues," e-mail message to author, April 10, 2012.

${ }^{76}$ Garrett Epps, "Constitutional Myth \#4: The Constitution Doesn't Separate Church and State," The Atlantic, June 15, 2011, accessed April 1, 2012.

${ }^{77}$ Kate Shellnut, "Michele Bachmann's Confusing Relationship with Jefferson," Perry Presidential, September 23, 2011, accessed April 10, 2012, http://blog.chron.com/rickperry/2011/09/michele-bachmann\%E2\%80\%99sconfusing-relationship-with-jefferson/.

${ }^{78}$ Anne Schroder Mullins, "Rep. Steve King, the Only Nay Vote," Politico, July 8, 2009, accessed April 11, 2012, http://www.politico.com/blogs/anneschroeder/0709/Rep_Steve_King_the_only_nay_vote.html.

${ }^{79}$ Ibid.

${ }^{80}$ Ibid.

${ }^{81}$ On The Issues, "Marilyn Musgrave on the Issues," OnTheIssues.org, accessed April 10, 2012, http://www.ontheissues.org/house/marilyn_musgrave.htm.

${ }^{82}$ Ibid.
} 
This paper has shown that the Christian right has been actively targeting the separation of Church and State in the United States through politically active organizations, campaign contributions and endorsements, and the support of U.S. politicians. Yet it is important address the 'why', that is, why is the Christian right so adamant about undermining or dismantling a legal precedent that ensures the free exercise of religion and a government that does not prefer one faith over another? The answers can possibly be found in three factors: Christian Dominion theology, shifting demographics, and the growth and increased visibility of irreligion in the United States.

Christian Dominion theology is a belief system within Christianity which asserts that Christians have a Biblical mandate to assume control over secular institutions of government. ${ }^{83}$. According to this belief, Christians must have complete control over government of not just the United States, but the world - a true 'dominion' - as a condition for the return of Christ as | prophesized by the Bible. ${ }_{-}^{84}$ The issue with Dominion theology is that is has been purported to be a potential theological rationale for the 'Christian nation' thesis. Dominion theology is generally not considered to be a part of mainstream Christianity in the United States, however it has gained increased prominence in the Christian right, with Michele Bachmann, Rick Perry, and Rick Santorum all having supposed connections to the movement, though substantive evidence of their involvement is difficult to come by. Bachmann has been associated with Truth in Action Ministries, an organization which has expressed Dominionist tendencies ${ }^{85}$, as has Rick Perry with the New Apostolic Reformation ${ }^{86}$. Santorum has spoken at the 2008 Christians United for | Israel conference, run by Pastor John Hagee, a Christian Zionist with Dominionist tendencies. ${ }_{-}^{87}$ While Christian Dominionism remains in the fringes of fundamentalist Christianity, its apparent rise in the evangelical community could be attributed to the so-called 'Armageddon factor', as described by Marci MacDonald in her book on the Canadian Christian right. This thesis asserts that some Christians believe that the Biblical end times are imminent if not already occurring, and as such it is the mandate of Christians to prepare their country for the return of Christ by assuming control of government. ${ }^{88}$

Demographics and changes in the U.S. religious landscape may also be a factor. The segment of the American populace that describes themselves as 'unaffiliated' to any organized religion currently is double the number that said they were unaffiliated as children- indicating a

\footnotetext{
${ }^{83}$ Theocracy Watch, "Dominion Theology," Religious Institutions and Beliefs, December 2006, accessed April 10, 2012, http://www.theocracywatch.org/relig_inst.htm\#Dominion.

${ }^{84}$ Ibid.

${ }^{85}$ Elizabeth Flock, "Dominionism: A 'dangerous' Christian Movement Influencing Michele Bachmann and Rick Perry?," Washington Post, August 16, 2011, accessed April 11, 2012,

http://www.washingtonpost.com/blogs/blogpost/post/dominionism-a-dangerous-christian-movement-with-aninfluence-on-michelle-bachmann-and-rick-perry/2011/08/15/gIQAydn5GJ_blog.html.

${ }^{86}$ Michelle Goldberg, "A Christian Plot for Domination?," The Daily Beast, August 14, 2011, accessed April 11, 2012, http://www.thedailybeast.com/articles/2011/08/14/dominionism-michele-bachmann-and-rick-perry-sdangerous-religious-bond.html.

${ }^{87}$ Daily Kos, "Rick Santorum Parties With Dominionist Pastor Hagee," DailyKos.com, February 23, 2012, accessed April 11, 2012, http://www.dailykos.com/story/2012/02/23/1064793/-Rick-Santorum-Parties-With-DominionistPastor-Hagee.

${ }^{88}$ Marci McDonald, The Armageddon Factor: The Rise of Christian Nationalism in Canada (Toronto: Random House Canada, 2010).
} 
measurable shift away from churches ${ }^{89}$ Additionally, the 'unaffiliated' also have the highest growth rate of any religious group. Furthermore, organized religion is not fairing well with America's youth, as 26 per cent of people aged 18-29 are reportedly unaffiliated, a far larger percentage than in any previous generation. ${ }^{90}$ Additionally, only one-third of people in this age category attend worship services on a weekly basis - again, the lowest attendance of any generation. ${ }_{-}^{91}$ Such shifts have put the religious right on the defensive, and their aggressive challenge towards the separation of church and state could be an effort to maintain dominance in an increasingly secular country. $\underline{\underline{92}}$

Protestant Christianity, of which most Christian fundamentalists adhere to, is also on the verge of losing its majority status in the United States, falling to about 51 per cent of the | population. ${ }^{93}$ At the same time, religion in the United States is becoming increasingly competitive, with all major religions gaining and losing adherents at the same time. ${ }^{94}$ While Muslims constitute a very small segment of the population at 0.6 per cent, immigration is fueling their growth, with new immigrants being four times as likely as Americans to be Muslim. ${ }_{-}^{95}$ It is perhaps changes such as this that has led the Traditional Values Coalition to make "securing the Constitution against the growing threat of Islam and Shariah law"96 one of their priorities. The seemingly increasing fear within the Christian right surrounding the growth of Islam in the United States could be a driving force in their goal to achieve Christian control of the government.

\section{Conclusion}

It is clear that the Christian right has a problem with the separation of Church and State as currently understood by the U.S. judicial system, and has engaged in a campaign to undermine or dismantle it in order to inject Judeo-Christian values into the formation of public policy. They have been able to pursue this agenda thanks to organizations such as the Family Research Council and its legislative arm, FRC Action, the Traditional Values Coalition, the Christian Coalition, Focus on the Family or CitizenLink. These organizations are well-financed and are the predominant lobbyists for the Christian right in Congress, while also endorsing and donating to political candidates that are sympathetic to their views. There are plenty of such politicians to go around - from Newt Gingrich, Rick Santorum, or Michele Bachmann as presidential contenders to Representatives like Steve King or Marilyn Musgrave.

Whatever motivates this belief against secularism - be it Dominion theology, the Armageddon Factor, or shifts in the religious landscape, there is an undeniable push to

\footnotetext{
${ }^{89}$ Pew Forum on Religion \& Public Life, "Summary of Key Findings," Statistics on Religion in America Report, February 2008, accessed April 11, 2012, http://religions.pewforum.org/reports.

90 "Religion Among the Millennials," Pew Forum on Religion \& Public Life, February 17, 2010, section goes here, accessed April 11, 2012, http://www.pewforum.org/Age/Religion-Among-the-Millennials.aspx. 91 Ibid.

92 "Rising Atheism in America puts 'religious right on the defensive"" The Guardian, October 1, 2011. Accessed December 17, 2012. http://www.guardian.co.uk/world/2011/oct/01/atheism-america-religious-right.

${ }^{93}$ Pew Forum on Religion \& Public Life, "Summary of Key Findings," Statistics on Religion in America Report, February 2008, accessed April 11, 2012.

94 Ibid.

95 The Pew Forum on Religion \& Public Life, U.S. Religious Landscape Survey, report (2008), 20.

${ }^{96}$ Traditional Values Coalition, "About," About - Traditional Values Coalition, accessed April 4, 2012.
} 
fundamentally alter the United States from a land of religious freedom to one where the Christian faith is given preference in the halls of government. However, the Christian right's campaign against secularism continues to be stymied by the courts of the United States, holding true to the precedent of the 1947 ruling in Everson v. Board of Education. In the 2006 case Hinrichs $v$. Bosma, a case in which the Family Research Council was involved, the Seventh Circuit of United States Court of Appeals ruled against the Christian right, reaffirming the separation of Church and State and ending the practice of Christian prayers in the Indiana State House of | Representatives. ${ }^{97}$ If the courts maintain this stance on the First Amendment, then the separation of Church and State will remain strong despite the threats against it.

| ${ }^{97}$ Hinrichs v. Bosma (United States Court of Appeals for the Seventh Circuit May 16, 2006). 


\section{Bibliography}

"About FRC." Family Research Council. Accessed April 1, 2012. http://www.frc.org/about-frc.

"About Us - Focus on the Family." Focus on the Family. Accessed April 10, 2012. http://www.focusonthefamily.com/about_us.aspx.

"About Us | CitizenLink." CitizenLink.com. Accessed April 10, 2012. http://www.citizenlink.com/about-us/.

"About." FRC Action. Accessed April 1, 2012. http://www.frcaction.org/about-us.

"Glossary of Religious and Spiritual Terms." ReligiousTolerance.org. October 15, 2008. Accessed April 11, 2012. http://www.religioustolerance.org/gl_v.htm.

"Jefferson's Wall of Separation Letter." Thomas Jefferson to Danbury Baptist Association. January 1, 1802. Accessed April 1, 2012. http://www.usconstitution.net/jeffwall.html.

"Made In America." Rick Santorum for President. Accessed April 11, 2012. http://www.ricksantorum.com/made-america.

"One Million Moms.com - Other Active Issues." One Million Moms.com. Accessed April 11, 2012. http://www.valueis.com/visit/onemillionmoms.com/activism.

"Religion Among the Millennials." Pew Forum on Religion \& Public Life. February 17, 2010. Accessed April 11, 2012. http://www.pewforum.org/Age/Religion-Among-theMillennials.aspx.

Benen, Steve. "A Frightening Forum in Iowa." The Washington Monthly. November 20, 2011. Accessed April 1, 2012. http://www.washingtonmonthly.com/politicalanimal/2011_11/a_frightening_forum_in_iowa033612.php.

Benen, Steve. "Gingrich's Nightmare тм." The Washington Monthly. November 20, 2011. Accessed April 1, 2012. http://www.washingtonmonthly.com/politicalanimal/2011_11/gingrichs_nightmare033613.php.

Center for Responsive Politics. "OpenSecrets.org: Money in Politics." OpenSecrets.org. http://www.opensecrets.org/.

CitizenLink. 2011 Annual Report. Report. September 2011. http://www.citizenlink.com/uploads/2010/07/FY2011FOTF295213_7_2011AnnualReport_CitizenLink_INTERACTIVE1.pdf.

Daily Kos. "Rick Santorum Parties With Dominionist Pastor Hagee." DailyKos.com. February 23, 2012. Accessed April 11, 2012. 
http://www.dailykos.com/story/2012/02/23/1064793/-Rick-Santorum-Parties-WithDominionist-Pastor-Hagee.

Dawson, Joesph M. "The Meaning of the Separation of Church and State in the First Amendment." Journal of Church and State 50, no. 4 (2008): 677-81.

Epps, Garrett. "Constitutional Myth \#4: The Constitution Doesn't Separate Church and State." The Atlantic. June 15, 2011. Accessed April 1, 2012. http://www.theatlantic.com/national/archive/2011/06/constitutional-myth-4-theconstitution-doesnt-separate-church-and-state/240481/.

Family Research Council. "Religion and Culture." Accessed April 1, 2012. http://www.frc.org/religion-culture.

Flock, Elizabeth. "Dominionism: A 'dangerous' Christian Movement Influencing Michele Bachmann and Rick Perry?" Washington Post. August 16, 2011. Accessed April 11, 2012. http://www.washingtonpost.com/blogs/blogpost/post/dominionism-a-dangerouschristian-movement-with-an-influence-on-michelle-bachmann-and-rickperry/2011/08/15/gIQAydn5GJ_blog.html.

Focus on the Family. "The Separation of Church and State." Social Issues. 2008. Accessed April 10, 2012. http://www.focusonthefamily.com/socialissues/social-issues/separation-ofchurch-and-state.aspx.

FRC Action. "Election Recap: The Return on Your Investment." News release. FRC Action.org.

FRC Action. "Santorum's Bid Ends - Values Campaign Continues." E-mail message to author. April 10, 2012.

Gibson, David. "Evangelicals Voting in Record Numbers in GOP Primaries." Washington Post. March 16, 2012. Accessed April 11, 2012. http://www.washingtonpost.com/national/onfaith/evangelicals-voting-in-record-numbers-in-gopprimaries/2012/03/16/gIQAlsi5GS_story.html.

Goldberg, Michelle. "A Christian Plot for Domination?" The Daily Beast. August 14, 2011. Accessed April 11, 2012. http://www.thedailybeast.com/articles/2011/08/14/dominionism-michele-bachmann-andrick-perry-s-dangerous-religious-bond.html.

Hinrichs v. Bosma (United States Court of Appeals for the Seventh Circuit May 16, 2006).

Horowitz, Alana. "Santorum: Separation Of Church And State 'Makes Me Want To Throw Up"' The Huffington Post. February 26, 2012. Accessed April 11, 2012. http://www.huffingtonpost.com/2012/02/26/santorum-church-and-state_n_1302246.html.

Hunter, James D. "The Culture War and the Sacred/Secular Divide: The Problem of Pluralism 
and Weak Hegemony." Social Research 76, no. 4, 1307-322. Accessed February 13, 2012. Political Science Complete, EBSCOhost.

Jr., Perry Bacon. "GOP Candidates Court Conservative Christians in Iowa." Washington Post. November 21, 2011. Accessed April 1, 2012. http://www.washingtonpost.com/politics/gop-candidates-court-conservative-christians-iniowa/2011/11/19/gIQAbN7VcN_story.html.

Kupelian, David. The Marketing of Evil: How Radicals, Elitists, and Pseudo-experts Sell Us Corruption Disguised as Freedom. Nashville, TN: WND Books, 2005.

McDonald, Marci. The Armageddon Factor: The Rise of Christian Nationalism in Canada. Toronto: Random House Canada, 2010.

Morone, James A. "Jefferson's Rickety Wall: Sacred and Secular in American Politics." Social Research 76, no. 4, 1199-226. Accessed April 11, 2012. Wilson OmniFile Full Text Select Edition.

Mullins, Anne Schroder. "Rep. Steve King, the Only Nay Vote." Politico. July 8, 2009. Accessed April 11, 2012.

http://www.politico.com/blogs/anneschroeder/0709/Rep_Steve_King_the_only_nay_vote .html.

Newt 2012. "Presidential Commission on Religious Freedom." Presidential Commission on Religious Freedom. December 19, 2011. Accessed April 10, 2012. http://www.scribd.com/doc/76090650/Presidential-Commission-on-Religious-Freedom.

On The Issues. "Marilyn Musgrave on the Issues." OnTheIssues.org. Accessed April 10, 2012. http://www.ontheissues.org/house/marilyn_musgrave.htm.

Pierard, R. V., and C. McDaniel. "Reappropriating History for God and Country." Journal of Church and State 52, no. 2 (2010): 193-202. doi:10.1093/jcs/csq080.

Posner, Sarah. "Gingrich's Anti-Secularism Greatest Hits | Religion Dispatches."

ReligionDispatches. November 29, 2011. Accessed April 10, 2012.

http://www.religiondispatches.org/dispatches/sarahposner/5445/gingrich $\% E 2 \% 80 \% 99$ s_a nti-secularism_greatest_hits.

Shellnut, Kate. "Michele Bachmann's Confusing Relationship with Jefferson." Perry Presidential. September 23, 2011. Accessed April 10, 2012.

http://blog.chron.com/rickperry/2011/09/michele-bachmann $\%$ E2\%80\%99s-confusingrelationship-with-jefferson/.

The Pew Forum on Religion \& Public Life. "Summary of Key Findings." Statistics on Religion in America Report. February 2008. Accessed April 11, 2012.

http://religions.pewforum.org/reports.

The Agora: Political Science Undergraduate Journal Vol. 3 No. 1 (2013) 
The Pew Forum on Religion \& Public Life. Religion in the Public Schools. Publication. 2007.

The Pew Forum on Religion \& Public Life. U.S. Religious Landscape Survey. Report. 2008.

Theocracy Watch. "Dominion Theology." Religious Institutions and Beliefs. December 2006. Accessed April 10, 2012. http://www.theocracywatch.org/relig_inst.htm\#Dominion.

Thistlethwaite, Susan Brooks. "Was Santorum Running for Theologian-in-chief?" Washington Post. April 10, 2012. Accessed April 11, 2012. http://www.washingtonpost.com/blogs/guest-voices/post/was-santorum-running-fortheologian-in-chief/2012/04/10/gIQARZYp8S_blog.html.

Traditional Values Coalition. "About." About - Traditional Values Coalition. Accessed April 4, 2012. http://www.traditionalvalues.org/content/about.

U.S. Congress. House. Bill Summary \& Status - Co-Sponsors. 109th Cong. H. H.R. 1070. Accessed April 2, 2012. http://thomas.loc.gov/cgibin/bdquery/z?d109:HR01070:@@@P.

U.S. Congress. Senate. Bill Summary \& Status. 109th Cong. S. S.520. Accessed April 2, 2012. http://thomas.loc.gov/cgi-bin/bdquery/z?d109:SN00520:.

U.S. Department of the Treasury. "History of 'In God We Trust"' August 3, 2011. Accessed April 1, 2012. http://www.treasury.gov/about/education/Pages/in-god-we-trust.aspx.

Walker, J. Brent. "The Meaning of Separation of Church and State in the First Amendment." Journal of Church \& State 50, no. 4 (2008): 693. Accessed April 11, 2012. MasterFILE Premier. 